\title{
Bulgarian tourism and the problem of poverty alleviation in Bulgaria
}

\author{
O turismo búlgaro e o problema da redução da pobreza na Bulgária
}

\author{
Preslav Mihaylov Dimitrov \\ South-West University "Neofit Rilski", Faculty of Economics, Tourism Department, \\ Blagoevgrad, Bulgaria, preslav.dimitrov@swu.bg
}

\author{
Rouska Kraseta \\ South-West University "Neofit Rilski", Faculty of Economics, Tourism Department, Blagoevgrad, Bulgaria, \\ rouska_bozhkova4@yahoo.gr \\ Boiko Dimitrov \\ South-West University "Neofit Rilski", Faculty of Economics, Tourism" Department, Blagoevgrad, Bulgaria, \\ boiko.dimitrov88@abv.bg \\ Petar Parvanov \\ South-West University "Neofit Rilski", Faculty of Economics, Tourism Department, Blagoevgrad, Bulgaria, \\ petarparvanov@gmail.com
}

\begin{abstract}
The present research paper summarizes the results from a broader research on the topic "Bulgarian tourism and the problem of poverty in Bulgaria" commissioned by the German Foundation "Fridrich Ebert", Sofia Bureau in 2014. Here, a more detailed literature review has been added to the one of the original research with the aim to follow the scientific discussion on this issue in the Bulgarian society for more than a century and to step on the more recent publications existing worldwide. The study examines the question about the ability of Bulgarian tourism to solve the problems with the widespread poverty in Bulgaria in the context of the two main issues such as: (i) the degree of association (in terms of Pearson's Product-moment coefficients) of the Bulgarian tourism with the economic performance of the EU tourism emitting economies, and whether this association in particular contributes for "transmission of poverty", and (ii) what will be the estimated volume of the average month salary of the employees on labor contracts in Bulgarian tourism for the next ten years by the HoltWinters exponential smoothing method. These two sub-questions, these two issues, have been chosen deliberately as the usual excuse of the representatives of the Bulgarian tourism industry for the much weaker results in comparison to the neighboring competing countries is that the tourists who come usually to Bulgaria from Western Europe are poorer. Another reason for the above posed questions is the contentiously repeated in the Bulgarian society "mantra" that the tourism sector in the country will grow on its own without any need of government support and direction and it will lead to a steady increase in the disposable incomes of the employed personnel. Although this claim might have appeared true for the end of the 1990s, the monthly level of salaries in tourism lags significantly behind many other service sectors in Bulgaria.
\end{abstract}

Keywords: Poverty alleviation, tourism, degree of association, exponential smoothing.

\section{Resumo}

O presente trabalho resume os resultados de uma investigação mais ampla sobre o tema "Turismo búlgaro e o problema da pobreza na Bulgária", encomendado pela Fundação Alemã "Fridrich Ebert" em 2014. Aqui, uma revisão bibliográfica mais detalhada foi adicionada à pesquisa original com o objetivo de seguir a discussão científica sobre esta questão na sociedade búlgara por mais de um século, baseada nas publicações mais recentes existentes em todo o mundo. O estudo examina a questão sobre a capacidade do turismo búlgaro para resolver os problemas da pobreza generalizada na Bulgária no contexto das duas principais questões, tais como: (i) o grau de associação (em termos de coeficientes de Pearson Produto-Momento) de o turismo búlgaro com o desempenho económico das economias emissoras de turismo da UE, e se esta associação em particular contribui para a "transmissão da pobreza", e (ii) qual será o volume estimado do salário médio mensal dos empregados em contratos de trabalho no turismo búlgaro para os próximos dez anos pelo método de suavização exponencial de HoltWinters. Estas duas questões foram escolhidas deliberadamente devido à desculpa habitual dos representantes da indústria do turismo búlgara para os resultados muito mais fracos em comparação com os países vizinhos é que os turistas da Europa Ocidental que vêm geralmente para a Bulgária são mais pobres. Outra razão para as questões colocadas acima é a repetida afirmação da sociedade búlgara de que o setor do turismo no país crescerá sozinho sem qualquer necessidade de apoio e direção do governo e levará a um aumento constante dos rendimentos dos empregados no setor. Embora essa afirmação possa parecer verdadeira no final da década de 1990, o nível mensal de salários no turismo fica significativamente atrás de muitos outros setores de serviços na Bulgária.

Palavras-chave: Alívio da pobreza, turismo, grau de associação, suavização exponencial.

\section{Introduction}

Since the dawn of the Bulgaria's transition to a market economy in the early 1990-ies of the 20th century, one of the most often repeated political "slogans" was that tourism, along with agriculture, is one of the sectors which could and should be relied upon for the prosperity of the Bulgarian nation in its transition to a market economy and beyond. Is the Bulgarian tourism really capable to solve the problems of the expending poverty in Bulgaria at the current state, when according to a number of political and economic analysts the transition to a market economy is already completed?

The present research tries to find an answer to this question by answering the two sub-questions: (i) "What is the degree of association of the Bulgarian tourism with the economic 
performance of the EU tourism emitting economies, and whether this association in particular contributes for transmission of poverty?" and (ii) "What will be the estimated volume of the average month salary of the employees on labor contracts in Bulgarian tourism for the next ten years?". These two sub-questions, these two issues, have been chosen deliberately as the usual excuse of the representatives of the Bulgarian tourism industry for the much weaker results in comparison to the neighboring competing countries is that the tourist who come usually to Bulgaria from Western Europe are poorer. Another reason for the above posed questions is the contentiously repeated in the Bulgarian society "mantra" that the tourism sector in the country will grow on its own without any need of government support and direction and it will lead to a steady increase in the disposable incomes of the employed personnel. Although this claim might have appeared true for the end of the 1990s, the level of salaries (on monthly payment basis, which is the practice in the country) lags significantly behind many other service sectors in Bulgaria.

\section{Literature and existing surveys review}

The first tries for scientific discussion in the Bulgarian society for fighting with poverty and for the potential role of travel and tourism precedes Bulgaria's liberation from the occupation by the Ottoman Empire in 1878. The first publication in this regard was made by the Bulgarian political statesman P. R. Slaveykov in 1869 in Konstantinopolis in a pamphlet published in the printing house of his own newspaper "Macedonia", in which he tried to present Benjamin Franklin's ideas for solving of the problem with poverty. Some more detailed analyses were published in 1892 by E. Dabev and in 1905 by E. Kalachev. In the 1930s, the publications of J. Kovachev (1936) and P. Hadjisotirov (1937), as well as the translated from Russian language paper of D. Hanry (1933) added to the efforts made by the Bulgarian Tourist Union and its Journal to convince the Bulgarian government to see tourism as a tool for overcoming the poverty and for the need of creation of a national tourism administration initially within the framework of the Bulgarian state railway company.

As for the modern research on the economic problem of poverty worldwide, one should inevitably point out the works of Harold W. Watts (1965) on the economic definition of poverty. The economics of poverty in poor countries was further researched by P. Dasgupta (1998). The concrete issue of tourism and poverty reduction was a subject of research by Walter Jamieson, Harold Goodwin and Christopher Edmunds (2004), as well as by Jonathan Mitchell and Caroline Ashley (2010) with a specific aim to understand whether a private sector service activity, like tourism, can reduce poverty in developing countries. The problem of reducing poverty through tourism felt in the focus of investigation by Dain Bolwell and Wolfgang Weinz (2008) from the International Labour Organization. The issue of tourism and poverty reduction felt into the attention of the discussion papers two more agencies of the United Nations, as follows: (i) the United Nations World Tourism Organization (2002); and (ii) the United Nations Development Programme (2011).

With the appearance of the mass tourism after the World War II a significant feature of the Bulgarian tourism industry came into life, i.e. the fact that it has always been one of the most open to the outside world sectors of the Bulgarian economy. And that has been a distinctive feature of the Bulgarian tourism sector even in the years of centrally planned economy and Soviet economic domination. As it is shown by the data provided by Bulgaria's former Ministry of Economy, Energy and Tourism and by the National Statistical Institute of the Republic of Bulgaria, a considerable part of the tourism consumers have always originated from the West European countries (Figure 1) and from the low-price market segments of these countries in particular.

Figure 1 - Some of Bulgaria's most important tourism markets

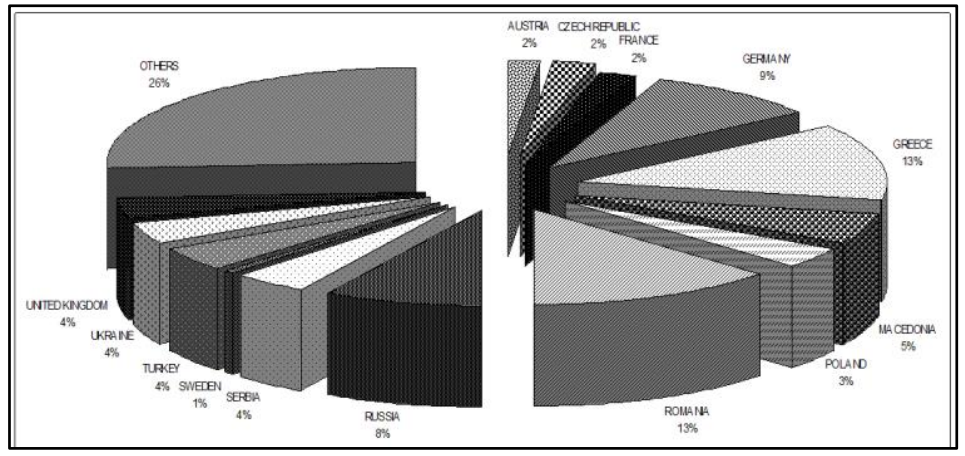

Source: Dimitrov, 2014.

The openness of the Bulgarian tourism made it especially susceptible to the consumers' disposable income and thus to the overall economic performance of the West European countries that are now members of the European Union. And as Tribes (2011, p.55), Page (2007, pp.68-69) and Uysal (1988, p.87) point out, whenever the disposable income of the consumers rises up, so does the tourism demand and vice versa. (Particularly at low price, or the so-called "poor" market segments). The exact association of the Bulgarian tourism industry with the economic performance of the EU tourism emitting economies, that are considered as important for the Bulgarian tourism receiving market, has never been measured. 
There were some qualitative evaluations in this regard (Rakadzhiiska, Stoyanov \& Diankov, 2010) (Stankova, 2010) (Neshkov \& Kazandzhieva, 2013, pp.92-99) (Freitag, 2010) but the degree of this association has never been a subject to a detailed calculation. The only precise figures that are being published by the former Bulgarian Ministry of Economy, Energy and Tourism, the newly created Ministry of Tourism and the Bulgarian National Statistical Institute refer to number of tourism arrivals and the percentage share of EU tourists in Bulgaria by country of origin and in total for the European Union (63.2\% for 2012, 60.5\% for $2013,60.6 \%$ for 2014 and 59.4 for 2015).

Further to this, based on a sample surveys conducted by the former Bulgarian State Tourism Agency (presently the Ministry of Tourism), as well as by the former Ministry of Economy, Energy and Tourism, it can be pointed out that the number of countries from Western Europe and Central and Eastern Europe are of a particular interest as target markets for Bulgaria's summer sea tourism. According to one of this survey conducted in 2008 , the countries that have the biggest shares of tourist coming to Bulgaria for summer sea tourism at the Black sea side are: Germany, United Kingdom, Russia, the Scandinavian countries (mainly from Sweden and Finland), Romania, the Czech Republic and Ukraine.

A brand development expert survey ordered by the Bulgarian Ministry of Economy Energy and Tourism and published in 2013 points out three groups of markets according to their priority for development: (i) markets with a very high priority for development: Germany, Russia, Romania, United Kingdom; (ii) markets with a considerably high priority: Greece, the Czech Republic, Poland, Netherlands, Ukraine; (iii) markets with a medium priority: FYR of Macedonia, Serbia, France, Austria, Israel and Hungary .

All the above research results and ranging of markets (Figure 2) evokes a particular interest on the measuring the Bulgarian tourism industry association with the economic performance of some EU tourism emitting economies, such as Austria, the Czech Republic, Finland, France, Germany, Greece, Romania, Sweden and the United Kingdom. This group of countries does not cover all the countries in Western Europe and in the European Union that are regarded as either main, or priority markets, as it is based also on the availability of data allowing a considerably long times series about their economic performance (by means of the GDP level in 1990's US dollars in particular).

Figure 2 - Percentage share of the EU countries as tourism emitting markets for the Bulgarian tourism

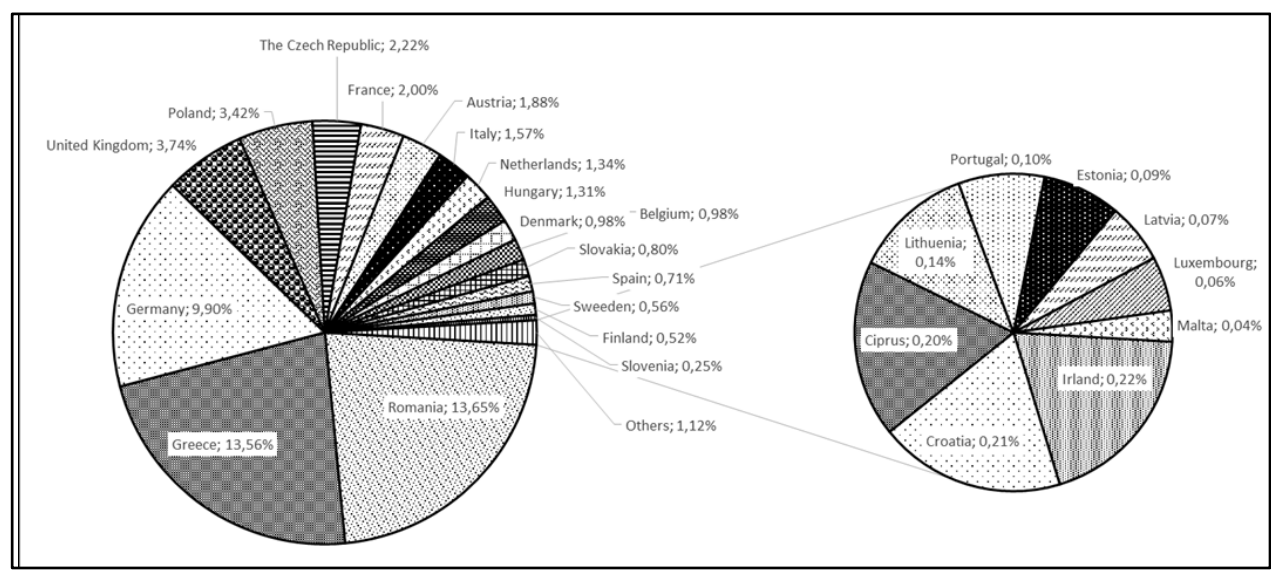

Source: Dimitrov, 2014.

\section{Methodology and main results}

3.1 The degree of association of the Bulgarian tourism with the economic performance of some the EU member states

For continuously related variables (Cooper \& Emory, 1995, p.478) there is a quite trivial approach for measuring of the degree of association by calculating the so-called Pearson product-moment correlation coefficients. The general mathematical notation of a Pearson product-moment coefficient is as follows (Cooper \& Emory, 1995, p.482-483) (Burns \& Bush, 2000, p.544):

$$
r_{x y}=\frac{\sum_{n}^{i=1}\left(x_{i}-\bar{x}\right)\left(y_{i}-\bar{y}\right)}{n s_{x} s_{y}},
$$

(1)

Where:

$x$ is each $x$ value; $x$ is the mean of the $\mathrm{x}$ values;

$\mathrm{y}$ is each $\mathrm{y}$ value;

$\bar{y}$ is the mean of the $Y$ values;

$\mathrm{n}$ is the number of paired of cases;

Sx, Sy are the standard deviations of $x$ and $y$, respectively.

The application of the above listed formula (1) is used in regard to the statistical information available of foreign visitors to Bulgaria with recreation and holidays aims and the gross domestic product of the member states of the EU (Figure 3). The statistical information used for the respective calculations is based on the data available from EUROSTAT, from the former Bulgarian Ministry of Economy, Energy and Tourism, from the present Ministry of Tourism, as well as from Bulgaria's National Statistical Institute. The statistical data in US dollars on 1990 price level for the GDP of Austria, the Czech Republic, Finland, France, Germany, Greece, Romania, Sweden and the United Kingdom, 
however, is available only after 1970 and therefore the regarded times series cover the time periods from 1970 to 2012.

Taking into account the results presented in Figure 3, it can be concluded that there is a strong positive linear correlation between the number of foreign visitors to Bulgaria with recreation and holidays aims and the variation in the values of the GDP for the selected EU countries, namely: Austria, the Czech Republic, Finland, France, Germany, Greece, Romania,
Sweden and the United Kingdom. The values of the correlation coefficients vary from 0.834 (for the GDP of Germany) to 0.904 (for the GDP of the Czech Republic) (Figure1). This strong positive linear correlation for all the regarded EU countries can be partly explained with the interdependence or crossassociation between the economies of these countries, which has also been demonstrated in the strong Pearson correlation coefficient between the GDP values of the separate economies.

Figure 3 - Pearson product-moment correlation coefficients - visual presentation

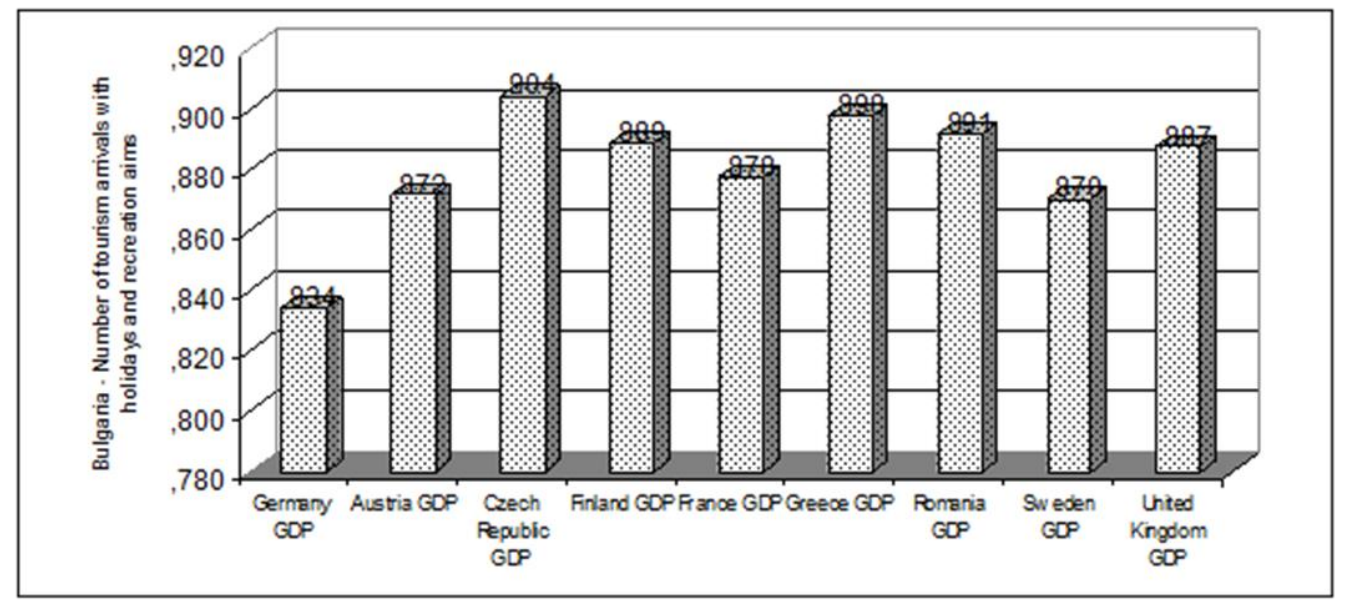

Source: Dimitrov and Krusteva, 2013.

Conclusions about the degree of association of the Bulgarian tourism with the economic performance of some EU member states, which serve as tourism emitting markets for the Bulgarian tourism:

(i) The result derived from the above presented analysis, which indicates a strong correlation between levels of GDP of the concerned EU-countries and the number of foreign visitors to Bulgaria with recreation and holiday aims;

(ii) This strong association also indicates one of the weaknesses of the Bulgarian tourism industry, and namely that it relies to a great extent on low-income and low-price customers.

(iii) The present study confirms the assumption and hypothetical claims about dependence of the Bulgarian tourism on low income markets that were a subject of discussion in the Bulgarian tourist scientific literature over the past three decades (Hadzhinikolov, 1988), (Rakadzhiyska, 1992), (Kostov, 1995), (Vodenska, 2006). And this very same dependence was indicated also as a major problem for Bulgarian tourism industry in reports for the sample surveys of the foreign visitors to Bulgaria, carried out by the former State Tourism Agency, the Former Ministry of Economy, Energy and Tourism and currently the Ministry of Tourism.

3.2 Forecasting the volume of the average monthly salary of the employees on labour contracts in the Bulgarian tourism until June 30, 2014

The available tourism data, published by the National Statistics Institute refer to the average salary of employees on labor contracts in the sub-sector of the hospitality industry, both on an annual and monthly basis (Figure 4).

Figure 4 - The average month salary in BGN of the employees on labor contracts hired in the hotels and restaurants for the period from January 01, 2000 to June 30, 2014

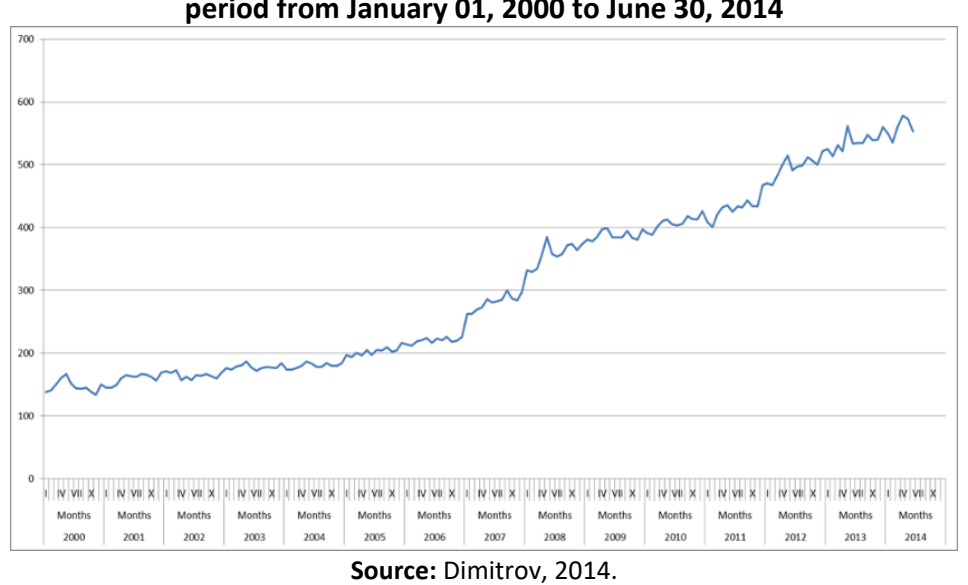


In present case of available monthly data, it is possible to use two of the variations of the exponential forecasting methods and in particular of the Holt-Winters method in the presence of: (i) "linear trend with multiplicative seasonality" (the "A, M" time series pattern) and (ii) "linear trend with additive seasonality" (the "A, A" time series pattern). Here, it is necessary to clarify that the term "seasonality" in the name of the forecast patterns (or profiles) is historically determined and it is used to denote the ordinary seasonal fluctuations, as well as all other cyclical changes in the development of time series.

The available monthly data since the beginning of the year 2000 allow us to build a relatively long time series of 174 time periods. The size of the time series on the average monthly salary of employees in the hospitality industry on labor contract allows one to seek an appropriate predictive technique and therefore suitable predictive model to extrapolate this indicator in the future. A possible solution in this regards could come in the face of the so-called "univariate" methods of forecasting (DeLurgio, 1998) and namely and most particularly in the group of the exponential smoothing methods. This group of methods relies on the assumption that if a considerably long time series of a certain indicator can be composed, this very same considerably long time series will have reflected all the possible external influences induced by all the possible external factors and thus time series will have incurred an internal logic of development and an internal information signal could be extrapolated further in future.

The mathematical notation of the Holt-Winters method for multiplicative seasonality is as follows:
(1)

The smoothing of the level (the base) - "B":

The smoothing of the trend - "T":

$$
B_{t}=\alpha \frac{Y_{t}}{S_{t-L}}+(1-\alpha)\left(B_{t-1}+T_{t-1}\right)
$$

$$
T_{t}=\beta\left(B_{t}-B_{t-1}\right)+(1-\beta) T_{t-1}
$$$$
0 \leq \beta \leq 1
$$

The smoothing of the seasonal (cyclicity) factor - "S":

$$
S_{t}=\gamma \frac{Y_{t}}{B_{t}}+(1-\gamma) S_{t-L}
$$

$$
0 \leq \gamma \leq 1 \text {, }
$$

The calculation of the final forecast " $\mathrm{Ft}+\mathrm{m}$ " for " $\mathrm{t}+\mathrm{m}$ " the period ahead of time:

(4) Where:

$$
F_{t+m}=\left(B_{t-1}+m T_{t-1}\right) S_{t+m-L}
$$

$" \alpha ",{ }^{\prime \prime}, \beta "$ and " $\gamma$ " are the smoothing constants for the base, trend and seasonality (cyclicity), which can take the value between 0 and 1 .

$>\quad$ The smoothing of the level (the base) - " $\mathrm{B}$ ":

$$
B_{t}=\alpha\left(Y_{t}-S_{t-L}\right)+(1-\alpha)\left(B_{t-1}+T_{t-1}\right)
$$

The smoothing of the trend - " $\mathrm{T}$ ":

$$
T_{t}=\beta\left(B_{t}-B_{t-1}\right)+(1-\beta) T_{t-1}
$$

$$
0 \leq \beta \leq 1
$$

The smoothing of the seasonal (cyclicity) factor - "S":

$$
S_{t}=\gamma\left(Y_{t}-B_{t}\right)+(1-\gamma) S_{t-L} \quad 0 \leq \gamma \leq 1
$$

And the mathematical notation of the Holt-Winters method in the presence of additive seasonality is as follows:

$$
0 \leq \alpha \leq 1
$$

The calculation of the final forecast " $\mathrm{Ft}+\mathrm{m}$ " for " $\mathrm{t}+\mathrm{m}$ " the period ahead of time:

(8)

$$
F_{t+m}=B_{t-1}+m T_{t-1}+S_{t+m-L}
$$

Where:

$" \alpha$ " , „ $\beta$ " и " $\gamma$ " are the smoothing constants for the base, trend and seasonality (cyclicity), which can take the value between 0 and 1.

For the level (base) "B0":

(9)

$$
B_{0}=\frac{1}{L}\left(Y_{1}+Y_{2}+\ldots Y_{L}\right)
$$

For the trend "TO":

$$
T_{0}=\frac{1}{L}\left(\frac{Y_{L+1}-Y_{1}}{L}+\frac{Y_{L+2}-Y_{2}}{L}+\ldots+\frac{Y_{L+L}-Y_{L}}{L}\right)
$$

For the seasonality (cyclic) factor - "SO": the seasonal factor " $\mathrm{S}$ " is achieved though the following set equations $(9,10,11$ and 12$)$ : 


$$
S_{0}=\frac{1}{N} \sum_{j=1}^{N} \frac{Y_{L(j-1)+i}}{A_{j}}
$$

$$
\forall_{i}=1,2, \ldots, L,
$$

Where:

$$
A_{j}=\frac{\sum_{i=1}^{L} Y_{L(j-1)+i}}{L}
$$$$
\forall_{j}=1,2, \ldots, N
$$

Aj represents the average value of $Y$ where $\mathrm{j}$ is the concerned time series.

$$
S_{o}=Y_{i} / B_{m}, \text { where } \mathrm{i}=1, \ldots, \mathrm{m} .
$$

However, the present paper will use equation (11) even if it is a little bit more complex to achieve and is close to an autoregressive approach for initialization of the seasonal indices.

Having selected the method of Holt-Winters for multiplicative and additive seasonality as appropriate predictive technique, we can proceed to calculate the corresponding forecasts for a period of ten years or until 30.6.2024 via using the software product "SPSS ${ }^{\circledR}$ "respectively for multiplicative and additive seasonality (Fig. 5 - with options for multiplicative seasonality) and (Fig. 4 - with options for additive seasonality). The comparison of the results of the various options in using the forecast method, or the methods based on errors in the forecasts, was achieved for the purposes of this study by using the mean absolute percentage of error - MAPE. Of course, it is possible to use other measures, as well as simultaneously with MARE, and independently to determine the optimal forecast
Here, for the initialization of the seasonal factor other alternative methods are also available and R. J. Hyndman (2014) recommends the following approach for the multiplicative seasonality: model. In this case the MAPE values are -2.051 at the HoltWinters' method for additive seasonality and 2.32 at the HoltWinters' method by using a multiplicative seasonality.

Conclusions about the possible effect from the forecasted average monthly salary in the tourism sector for the next ten years (until 06/30/2024):

As it is obvious from Fig. 5 and 6 , there is a clear and steady trend of a gradual increase in the average monthly salary in the tourism sector and particular in the sub-sectors of the hotels and restaurants. After a careful analysis of this seemingly positive trend, however, one can point out that the forecasts for the end of the forecast period, achieved respectfully by the method of Holt-Winters for multiplicative seasonality and the method of Holt-Winters for additive seasonality are, as follows: 906 BGN (by the method of the Holt-Winters with multiplicative seasonality) and 887 BGN (by the method of Holt-Winters with additive seasonality).

\begin{tabular}{|c|c|c|c|}
\hline & & & Model Type \\
\hline Model ID & Monthly salary & Model_1 & Winters' Multiplicative \\
\hline
\end{tabular}

Figure 5 - Graphical presentation of the forecast results in the method of Holt-Winters for multiplicative seasonality for the

\begin{tabular}{|c|c|c|c|c|c|c|}
\hline \multicolumn{7}{|c|}{ Exponential Smoothing Model Parameters } \\
\hline Model & & & Estimate & SE & $\mathrm{t}$ & Sig. \\
\hline \multirow{3}{*}{$\begin{array}{l}\text { Monthly } \\
\text { salary }\end{array}$} & \multirow[t]{3}{*}{ No Transformation } & Apha (Level) &., 506 & .043 & 11,658 &, 000 \\
\hline & & Gamma (Trend) & .000 & ,003 & .046 & ,964 \\
\hline & & Delta (Season) & .521 & 091 & 5,710 & .000 \\
\hline
\end{tabular}
period until June 30, 2024

Model Description

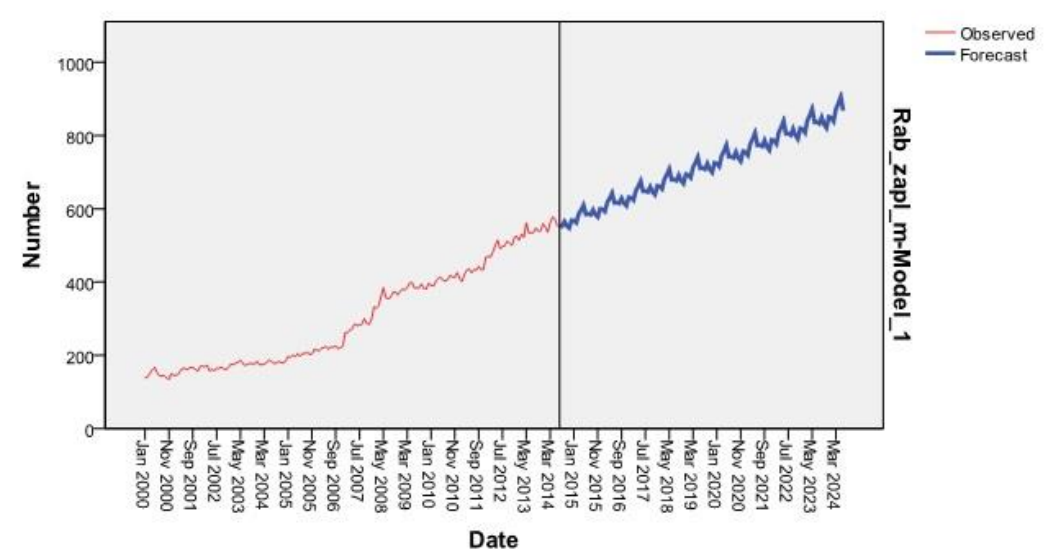

Source: Authors' calculations according to data provided by the Bulgarian National Statistical Institute. 
Figure 6 - Graphical presentation of the forecast results in the method of Holt-Winters for additive seasonality for the period until June 30, 2024

\begin{tabular}{|ll|l|}
\hline \multicolumn{3}{|c|}{ Model Description } \\
\hline Model ID & Monthly salary & Model Type \\
\hline
\end{tabular}

Exponential Smoothing Model Parameters
\begin{tabular}{|lrl|r|r|r|r|}
\hline Model & & & Estimate & \multicolumn{1}{c|}{ SE } & \multicolumn{1}{c|}{ S } & \multicolumn{1}{c|}{ Sig. } \\
\hline $\begin{array}{l}\text { Monthly } \\
\text { salary }\end{array}$ & No Transformation & Alpha (Level) &, 809 &, 076 & 10,684 &, 000 \\
& & Gamma (Trend) & $1,391 \mathrm{E}-5$ &, 004 &, 003 &, 997 \\
& & Delta (Season) &, 001 &, 112 &, 009 &, 993 \\
\hline
\end{tabular}

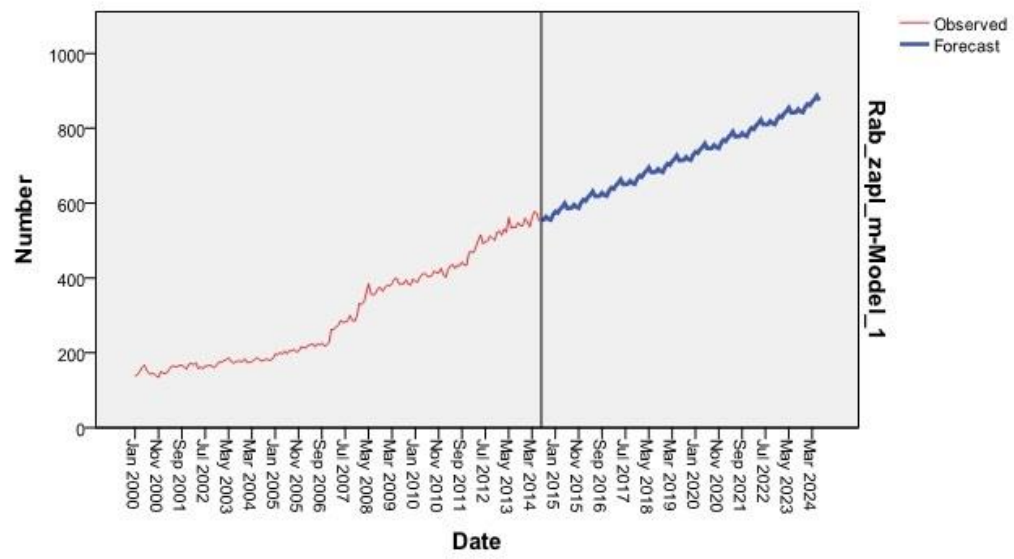

Source: Authors' calculations according to data provided by the Bulgarian National Statistical Institute.

And if one takes into account the values of MAPE, i.e. that this indicator has its lowest value for the method of Holt-Winters with additive seasonality, it appears that the most optimal forecast of the average monthly salary in the hospitality industry in Bulgaria, up to 06.30 .2024 , would be 887 BGN. At maximum value recorded for the period 01.01.2000 06.30.2014 of 578 BGN (April 2014, equivalent to 295.52 Euros) and final value recorded in this study of 553 BGN (June 2014, equivalent to 282.74 Euros), this means that for the next ten years the average salary in the hotels and restaurants in Bulgaria will increase in comparison to the maximum recorded value only by 309 BGN (157.98 Euros), and in comparison to the last recorded value only by 321 BGN (164.12 Euros)!

\section{Conclusions}

There is a strong association, a strong correlation between levels of GDP of the concerned EU-countries and the number of foreign visitors to Bulgaria with recreation and holiday aims.

This strong association also indicates one of the weaknesses of the Bulgarian tourism industry, and namely that it relies to a great extent on low-income and low-price customers.

At maximum value recorded for the period 01.01.2000 06.30.2014 of 578 BGN (295.52 Euros, April 2014) and final recorded value of 553 BGN (282.74 Euros, June 2014), for the next ten years the average salary in the sectors of the hotels and restaurants in Bulgaria will increase in comparison to the maximum recorded value only by 309 BGN (157.98 Euros), and in comparison to the last recorded value only by 321 BGN (164.12 Euros)!
Based on the above findings and taking into account of the current market positioning of the Bulgarian tourism industry in regards to the tourist emitting markets of the EU countries, one may draw the conclusion that Bulgarian tourism neither will increase the welfare of the Bulgarian nation, nor it is capable to solve the problems of poverty in the country, and that it rather brings in poverty through the low-price customers coming from the EU member countries.

\section{References}

Bolwell, D. \& Weinz, W. (2008). Working paper Reducing poverty through tourism. International Labour Office: ILO Sectorial Activities Programme - Geneva. Retrieved May 14, 2016 from http://www.ilo.org/wcmsp5/groups/public/@ed_dialogue/@sector/d ocuments/publication/wcms_162268.pdf .

Burns, A. C., \& Bush, R. F. (2006). Marketing Research, (5th ed.). UpperSaddle River, New Jersey: PearsonPrenticeHall.

Cooper, D. C. \&Emory, C. W. (1995). Business Research Methods, (5th ed.). Boston: IRWIN, The McGraw-Hill Companies Inc.

Dabev, E. (1892). The justice of the poor. Pazardzhik, Bulgaria: Printing House "Ts. P. Radoulov".

Dasgupta, P. (1998). The Economics of Poverty in Poor Countries. Retrieved on May 14, 2016 from http://eprints.lse.ac.uk/6684/1/The_Economics_of_Poverty_in_Poor_ Countries.pdf.

Dimitrov, P., Krasteva, R. \& Kalaydzhieva, V. (2013). Association of the Bulgarian Tourism Industry with the Economic Performance of Some EU Tourism Emitting Economies. In José António C. Santos (Ed.), Strategies in Tourism Organizations and Destinations (pp. 177-188). Faro, Portugal: University of the Algarve.

Dimitrov P. (2014), Can the Bulgarian Tourism solve the problem with poverty in Bulgaria?, In G. T. Gantchev (Ed.), The Fight with Poverty in Bulgaria: Macroeconomics, Ethical Aspects, Eurvintegration, the Role of 
Tourism (pp. 105-119). Fridrich Ebert Stiftung: Beureau Bulgaria \& Institute for Economics and International Relations, Sofia.

Freitag, R. (2010). Studies of ten generating markets (a presentation). Project BG161P0001/3.3-01/2008/001-1 "Marketingresearches and evaluation of effectiveness of the national marketing" funded under Operational Programme Regional Development of the Ministry of Economy, Energy and Tourism. Retrieved June 15, 2013 from http://www.mi.government.bg/files/useruploads/files/turism -

_statistika_i_analizi/prouchvania_proekti/prouchvania_10generirashti pazara_2010.pdf

Hadzhinikolov, Hr. (1988). Economics and planning in tourism. Sofia, Bulgaria: Sofia's University publishing house „Kliment Ohridski“.

Hadzhisotirov, P. (1937). Towards personal and social wealth: The Way of the Oxford Group. Sofia, Bulgaria: Nov Zhivot

Hanry, D. (1933). Progress and Poverty: A Study on the Economic Crises and the Poverty that increases with the increase of Wealth: Means for Alleviation. Sofia, Bulgaria: Posrednik.

Jamieson, W., Goodwin, H. \& Edmunds, C. (2004). Contribution of tourism to poverty alleviation - pro-poor tourism and the challenge of measuring impacts. UN ESCAP: Transport Policy and Tourism Section Transport and Tourism Division. Retrieved on May 14, 2016 from http://haroldgoodwin.info/resources/povertyalleviation.pdf.

Kalachev, P. (1905). Something on the poverty and the families of school students in the capital. Sofia, Bulgaria: Printing House "P. Kalachev".

Kovachev, J. (1936). On fight with Poverty! Sofia: Zadruga

Kostov, E. (1995). The trough about Bulgarian tourism: Yesterday, Today, Tomorrow. Sofia, Bulgaria: University publishing house "Stopanstvo".

Mitchel, J. \& Ashley, C. (2010). Tourism and Poverty Reduction Pathways to Prosperity. London: Routledge

NATIONAL STATISTICAL INSTITUTE (2013a). Statistical Yearbooks of the People's Republic of Bulgaria for the period 1964-1989.

NATIONAL STATISTICAL INSTITUTE (2013b). Statistical Yearbooks of the Republic of Bulgaria for the period 1990-1999.

Neshkov M., Kazndzieva V. (2013). Macro-regulation of tourism business. Varna, Bulgaria: Publishing House „Nauka i ikonomika“.

Page, S. J. (2007). Tourism Management - Managing for change, (2nd ed.). Oxford, UK: BookPower \& Butterworth-Heinemann Limited (an imprint of Elsevier).

Slaveykov, P. R. (1869). The poor Bogdan or a way to become enriched: a pamphlet that is much recommended for the people. Constantinople: the printing house of the "Macedonia" newspaper.

Stankova, M. (2010). The Tourism Regions in Bulgaria - Concepts and Challenges. Journal of Tourism \& Hospitality Management, 16(1), 109118.

Tribe, J. (2011). The Economics of Recreation, Leisure and Tourism, (4th ed.). Oxford: Butterworth-Heinemann (an imprint of Elsevier).

Rakadzhiyska, S. (1992). Tourism marketing and advertising. Varna, Bulgaria: Publishing House „Galactica“.

Vodenska, M. (2006), Tourism and society. Sofia, Bulgaria: publ. International Business School;

Uysal, M. (1998). Destination Marketing: A New Perspective, In Hypertext on Tourism Marketing (CD-ROM). Eds. G. Peroni et al. Italy.

United Nations Development Programme (2011). Discussion Paper Tourism and Poverty Reduction Strategies in the Integrated Framework for Least Developed Countries. Retrieved May 14, 2016 from http://unwto.org/sites/all/files/pdf/undp_discussion_paper_tourism_ and_poverty_reduction_strategies_in_the_integrated_framework_for _least_developed_countries.pdf.

United Nations World Tourism Organization (2002). Tourism and Poverty Alleviation. Retrieved May 14, 2016 from http://www.eunwto.org/doi/pdf/10.18111/9789284405497
Watts, H. W. (1965). An Economic Definition of Poverty. Madison, Wisconsin: The University of Wisconsin. Retrieved on May 14, 2016 from http://www.irp.wisc.edu/publications/dps/pdfs/dp568.pdf.

Received: 18.03 .2017

Revisions required: 25.11 .2017

Accepted: 12.02 .2018 